Jurnal ASPIKOM, Vol. 7, No. 1, January 2022, pp. 158-172

P-ISSN: 2087-0442, E-ISSN: 2548-8309

DOI: http://dx.doi.org/10.24329/aspikom.v7i1.1046

\title{
News Framing about Physical Construction in Jakarta Flood Management
}

\author{
Damayanti Wardyaningrum \\ Universitas Al-Azhar Indonesia, Jl. Sisingamangaraja No. 2, DKI Jakarta, Indonesia \\ *Corresponding author, e-mail: damayanti@uai.ac.id
}

\begin{abstract}
The 2020 flood in Jakarta has brought people's attention as it paralyzed the city's activities. Different than other kinds of natural disaster like earthquake, tsunami, and mountain eruption, flood in Jakarta is a predictable event that could have been anticipated. In natural disasters, there should be a study to acquire the description of media coverage tendency toward the issue. The objects of this research are news published by Kompas (print media) during and post-flood disaster by using the framing method with four elements syntaxis, script, thematic, and rhetoric. The result suggested that news framing focuses no longer on the victims' misery but on the comprehensive review with highlighted the rational argumentation flood handling from physical construction and resulted in meaningful information on mitigation effort so that natural events would not transform into disaster.
\end{abstract}

Keywords: Flood handling; Jakarta; News framing

\begin{abstract}
Abstrak
Peristiwa banjir yang terjadi pada tahun baru 2020 menyita perhatian publik karena terjadi di wilayah ibu kota Jakarta dan melumpuhkan kegiatan bisnis bahkan hingga kota-kota disekitarnya. Berbeda dengan jenis bencana alam lainnya seperti gempa, tsunami, dan letusan gunung yang terjadi di Indonesia, banjir di DKI periode terjadinya hampir dapat diprediksi. Pada peristiwa bencana alam perlu dilakukan kajian untuk memperoleh gambaran kecenderungan fokus pemberitaan yang muncul. Objek penelitian dilakukan pada berita di media cetak Kompas selama terjadi bencana dan pasca bencana banjir DKI 2020 dengan metode framing melalui elemen sintaksis, skrip, tematik dan retorik.. Hasil penelitian menemukan framing berita pada tinjauan komprehensif yang tidak lagi memberitakan masalah korban, namun fokus pada penjelasan pada aspek konstruksi fisik dan menghasilkan informasi yang bermakna tentang upaya mitigasi agar tidak menjadi bencana.
\end{abstract}

Kata Kunci: Framing berita; Jakarta; Penanganan banjir 


\section{Introduction}

For the past 20 years, hydrometeorology disaster resulting from global warming has haunted Indonesia. The nation's loss because of that disaster has reached approximately 20 billion rupiahs every year. Most of them are from floods and landslides. Based on the record, hydrometeorology disasters happened the most often during the year 2018, reaching the number of 96,8\%, while the remaining 3,2\% were other geology disasters. Even though hydrometeorology disasters happened more often, looking at the number of lost persons and fatalities geology disasters, the geology disaster was still the number one contributor in 2018 (Rosyida et al., 2019).

One of the hydrometeorology disasters that has been in the spotlight, including international media, is the flood disaster in DKI Jakarta in early 2020. This flood disaster has impacted various business and tourism sectors. The flood disaster that took place 1-5 January 2020's loss has reached about 1,045 billion rupiahs (Kompas, 2020). The loss impacted not only the retail selling in traditional markets and malls but also transportation businesses, including online transportation. The tourism sector that usually reaps most revenue during the new year's celebration had to endure billion rupiahs of loss. The shopping centers reported losing more than 50 percent of visitors during that week.

Flood not only took place in Jakarta but also in the surrounding cities like Tangerang and Bekasi in West Java. Many public services have been disrupted, namely electric railways that are supposed to carry thousands of workers to their workplace because the tracks were flooded. Jakarta is known as the center of national economic activity. Therefore, once floods crippled the city, the economic activities were crippled too, and so was productivity.

In every natural disaster, media has a strategic role not only to cover the disasters' facts but also to educate society. Generally, in the event of a disaster, media is more focused on bringing up the data about the emergency response and the victims' misery and financial loss. The tendency of message content in the news of disaster events usually media exploiting the suffering of disasters' victim, and giving less attention to the information on disaster mitigation (Sukmono \& Junaedi, 2018).

Today's media should have played a bigger role in providing solution to mitigate disaster. At the post-disaster phase or the recovery stage, the media need to convey how victims should survive and continue their lives. Furthermore, on the disaster event that happens repeatedly, media should not take an angle of victims' misery (even worse dramatizing it) or the helping and support towards victims, but more importantly, is how the media create a coverage on finding out the cause of the disaster and how to mitigate the risks. This argument is in accordance with the concept that mentions why society consumed mass media for its surveillance function. Besides its function as entertainment, media can be utilized as people's company in everyday life. On surveillance function, society uses media to monitor all kinds of information happening, both in their surroundings and worldwide (Turow, 2014). In the case of the Jakarta flood disaster, people would like to immediately find out about the most recent condition of the area impacted by the flood, how many houses submerged, et cetera.

In a prone disaster country like Indonesia, the media's strategic role in educating the public is mandatory. Media should keep providing information to be basic recommendation principles for society on how to react to prevent, deal with and act thoroughly during pre, on, and post-disaster events. The regular information provided by the media could serve as the early warning system for society. Media should warn 
people that they live in a prone disaster area. Thus, they have to be ready anytime to deal with the disaster. Media can not prevent disaster, but they can prevent more victims by reducing society's hysteria because of irresponsible issues and rumors.

Media information and appeals should be accounted scientifically for their capacity to publish coverage on natural disasters. At least the information provided should be accepted by common sense, are not conveyed bluntly, and must consider the various effects on the public, especially the victims. The public requires accurate, factual, and relevant information, not the entertainment and merrymaking events that could be perceived as insensitive to victims. In a disaster event, there is much mazy information about the cause and how to manage the disaster. Therefore, media play a significant role in clearing the facts and giving society proportional enlightenment accordingly.

Thereby whole related parties on this event could be brought to the issue concerning disaster mitigation. If a disaster is unavoidable, the harmful impact of predictable and repeated natural disasters could be minimized gradually. Moreover, this is the kind of natural disaster that initially was a regular nature phenomenon that turned into a disaster because of the wrongdoing habits of humans who live in the area.

The facts about disasters have been widely discussed in the media. However, the idea of Greenberg \& Scanlon (2016) has become crucial because the media construction should have presented the more important things like the mitigation efforts and the correct emergency response until the recovery process.

Media serves an essential role in disaster events. The result of the study on print local media Fajar and Tribun Timur on flood disaster suggested that media play a meaningful role in the mitigation of flood by bringing awareness to society both on the period of pre-, during, and post-flood disaster. The news is quite objectives with significance on news accuracy, news completeness, as well as news checking (Rahayu et al., 2014). This is in line with the study about flood-prone areas and handling solutions in Puring Sub-District, Kebumen, Central Java. This information is crucial to passing to the public during the pre-disaster period (Mardikaningsih et al., 2017). Another study relevant to the abovementioned is about the history of flash floods in Indonesia. It was found that there are certain characteristics and solutions to overcome flash flood disasters by making several mitigation efforts, for example, by mapping the dangerous area by using the early warning system, building public's preparedness and the forecasting of hydrometeorology. Unfortunately, from the studied mitigation efforts, only some potential flood disaster areas are ready with such preventive precautions (Adi, 2013).

Furthermore, by studying the reason for flood events in other areas, people can also learn from the media to mitigate the flood potential in their respective areas. For example, a study found that two factors caused the flood in Samarinda. First, natural factors like the high rate of rainfall, area topography, and tidal water in the river of Mahakam. Second, people's growth is followed by the increase in infrastructures needs, residential, clean water, education, and other public services (Setiawan et al., 2020). From all pre-flood disaster events explained, therefore, the role of mass media in information and education should be elevated to let people understand the importance of preparedness in facing the potential of flood disaster.

If we refer to coverage of disaster events in other developing countries, this condition is similar to the number of countries. One of them is Pakistan, an Asian 
country that experiences floods annually. In his research about the role of media in Pakistan, Zaheer (2016) concludes that after the magnificent earthquakes in 2005 and 2014 , media has been more successful in encouraging province and central government to provide food and medications for disaster victims immediately. On the other side, the media's role is still lacking on the long period post-disaster in which victims still need support. Media also still lacks its substantial role during and pre-disaster to encourage people's preparedness. The recommendation of this study was to create a media management organization, disaster management body, and policymaker to build cooperation to overcome various problems in handling the disaster.

In the motive of media's work in transferring information on the disaster coverage, a number of audiences, both readers or viewers, depend on the updated information from media. The story on the news brings awareness about victims' and survivors' misery, which finally lets the audience think of how to support and contribute to helping them. However, in reality, the media are under pressure to not think of how to rescue and evacuate the victims and survivors. While they are on the disaster's spot, their main priority is broadcasting news with complete information (Ali, 2013).

The coverage on disaster also emphasized the dramatic effect and sorrow after disaster, while putting less attention on disaster mitigation. The news about rehabilitation and reconstruction post-disaster is almost absent. At the same time, reconstruction and rehabilitation could trigger another news disaster because of the gaps (Arif, 2014). Another study about disaster coverage explained that television has more tendency to transform objective reality from news to be merely something to watch during the Merapi eruption in 2010. The construction of the news was about disrupting moment, panic moment, and uncertain moment (Noviani, 2012).

In a disaster, television channels often compete to broadcast the most exclusive news. News is important to the public, but the way media cover the story often creates a "phenomenal effect" in society. For example, the news of the volcano disaster should be presented correctly because the public misperceives many technical issues if the reporter or presenter is not aware of the eruption that would bring psychological effects to society (Subiyanto, 2016). From a study on disaster coverage, Nazaruddin (2015) also found that in the situation of uncertainty caused by disaster events, the public's need for news will increase significantly and encourage more intensive news coverage by mass media.

On the other side, some media have played an essential role in the event of a disaster. The synergy of including mass media and society can contribute better by using media. Another study highlighted that integrated disaster communication optimization is crucial in disaster management. Harian Pagi Rakyat Riau has played a role as a channel in the communication process of disaster risk in the phase of disaster management (Annapisa, 2018). In the event of the Mount Sinabung eruption, online media has played a role in disaster coverage. However, it is recommended that news coverage not only focus on emergency response but also cover the pre and post-disaster (Lestari et al., 2018).

This condition is in line with other prone disaster countries like Pakistan that experience floods annually. Research about the media's role in Pakistan concluded that after two magnificent earthquakes in 2005 and 2014, the media managed to encourage the government, both local and central, to provide food and medicine for the victims immediately. However, on the other side, media still lacks its role in the post-disaster period in which the victims still need their support. Media was not considered to play a 
substantial role in a disaster event. Moreover, the media was not present at the predisaster event to encourage people's alertness (Zaheer, 2016).

Disaster communication also determines the government's success in providing information for people's safety. Handling disaster in an integrated manner is crucial in disaster management, synergy by involving mass media and society in information distribution (Asteria, 2016). This aligns with the study on the importance of hydrometeorology disasters for society. A better understanding of the hydrometeorology aspect is a substantial factor in building a better culture of disaster awareness. The aspect of hydrometeorology like characteristics of weather and climate, forecasting the extreme weather and climate, and good surveillance are essential inputs to develop a disaster handling system and create a disaster awareness culture (Sarvina, 2018).

Disaster coverage on media can positively affect people's awareness (Istiqomah, 2019). One of its suggestions is to create a learning module that uses an approach that is a learning strategy to raise alertness to handle the disaster. For example, when there was an eruption in mount Raung. There was a media that suits teachers very well and can be applied using Facebook (Handayani et al., 2018). The role of social media seemed to be dominant. For example, during the tsunami in Japan in 2011 with the high use of Twitter and Facebook. These social media really helped people in and outside Japan share information concerning aid distribution, the search of missing people, medical assistance for the wounded, helping disabilities, and encouraging moral support (Peary et al., 2012). Even the use of social media has been high and provided sufficient contribution, the presence of printed media is still required.

Moreover, not all conditions support the operation of social media because it all depends on the infrastructures in the area in which disaster occurs. In Indonesia, many prone disaster areas are not covered by the telecommunication network infrastructure. On the other side, disaster news coverage prioritizes the speed of news broadcasting and stresses sensationalism instead of considering what kind of news serves society better (Haryanto, 2018).

Flood disaster in DKI Jakarta on the first day of 2020 provoked many people to share their print media opinions. Aside from news of the casualties and financial loss of the victims, some articles connected the history of flood in DKI Jakarta since the colonial era, including various infrastructure and technical methods to anticipate the high rate of rainfall that should have been done before the rainy season comes. Flood problems in DKI Jakarta have attracted much attention from the media. Therefore, it should be studied how media frame the disaster event in early 2020. The researcher chose this case through the study of media news based on some considerations: 1) hydrometeorology disaster is the impact of repeated natural phenomenon every year, so its characteristics should be studied for disaster mitigation; 2) to give contribution on the implementation of policy for the next rainy season; 3) with the huge number of financial loss thus DKI Jakarta flood coverage should attract public attention proportionally.

The selection of Kompas as the object of this study is based on its reputation as print media with national circulation and one of the most credible media in Indonesia. The work of print media is bound by the professional codes that have been kept and held firmly. As one of the essential mass media instruments, print media has served as an informative communication bridge between the nation and its people. Pers has a role in presenting trustworthy information flow with regard to disaster handling and its 
adequate analysis so that the news presented can become references for evaluation and decision of anticipative action.

\section{Method}

This research approach is qualitative by obtaining in-depth data that support meaning. Meaning is the actual and exact data that serves as a value behind the actual data. Therefore, qualitative research does not stress generalization but more on the meaning. In this study, the data used are news coverage on media.

The strategy of this research is using the framing approach to obtain how perspective or point of view is used by the journalist in selecting issues and writing news. As noted by Todd Gitlin, framing is a strategy of how the reality of the world is being shaped and simplified as presented in the news to make it stand out and attract the readers' attention. The frame is the principle of selection, emphasis, and presentation of reality (Eriyanto, 2002).

The design of this research uses the analysis model of framing by Pan and Kosicki, which operationalizes four structure dimensions of news as framing tools: syntaxis, script, thematic and rhetorical. Those four dimensions create a theme that reconciles news narration's semantic element into a global coherence (Sugiyono, 2010).

\section{Results and Discussion}

The researcher found thirty-five news coverage on DKI Jakarta flood during January - February 2020 and then divided this news into four dominant issues categories: 1) evaluation on flood disaster; 2) land acquisition; 3) debate on normalization versus naturalization; 4) history of flood; and 5) other areas affected by DKI Jakarta flood. The framing result uses Pan and Kosicki in the view of the researcher. It appears that Kompas media construct their news with the perspective of civil construction and flood control management. Below are the examples of five news analyzed:

\section{News 1: Disaster Control Evaluated (9 January 2020)}

President Joko Widodo has instructed all parties to evaluate the disaster control system in the Jabodetabek area. The master plan of flood control should be implemented to avoid the same disaster occurring in the future. President Jokowi explained that the master plan of the nation's capital and surrounding flood control had existed long ago. However, this master plan has not been fully implemented. Cooperation between central, province, regency, and city governments must implement the disaster control master plan.

In another paragraph, the DKI Jakarta Governor explained their preparation for dealing with medium-up to heavy rain.

Anies noted that to anticipate rain, posts are being built from the village level to respond whenever there is a puddle. Head of Water Resource Office DKI Jakarta, Juaini Yusuf, said that when the flood happened in early January, all 474 stationer pumps and 122 moving pumps were functioning well. However, some pumps must be stopped immediately because they are submerged in flood. Some of them are in Teluk Gong and Semanan. Also, some pumps were turned off as the flood submerged them. Semanan is also a basin area. The pump that is still moving there was used to dampen the water. 


\section{News 2: DKI Jakarta Will Conduct Land Acquisition (14 January 2020)}

This news is about the plan of land acquisition to normalize the river

The acquisition of 118 lands to continue the Kali Ciliwung normalization program will be done by early April 2020. Head of Water Resource Office DKI Jakarta said that "Currently, we are on inventory process because once all documents are completed, and budget is approved, it will be settled". From the requirement of 18.097 square meters, the acquired land for "crossing" the Ciliwung river is 5967 square meters. The remaining 12.130 squared meter is not on the acquisition year. Currently, the building of "crossing" in Ciliwung has reached $50 \%$ out of 1.200 meters"

Still, on the same topic of the article, there is a review about DKI Jakarta's Lawsuit toward Governor, Illegal Mining in Bogor that caused flood and new about Document Restoration Service.

Two hundred forty-three people of Jakarta have put a lawsuit against DKI Governor for his negligence in anticipating the Jakarta flood in early 2020. That negligence has caused financial loss. The lawsuit was registered to Central Jakarta District Court on Monday. They joined a lawsuit team called "Class Action” DKI Flood 2020. The total number of losses was reported about 42,3 billion rupiahs.

The legal counsel of the plaintiff, Alvon Kurnia Palma, explained that DKI Governor had become the defendant because the Jakarta flood in early 2020 is a local type. DKI Provincial Government should have understood the area topography and been more agile in warning the people around the flood area. "In reality, people who live in basin area or nearby the river have never been warned. If only the government had understood that the area was prone to flood, their response should have been quicker.

\section{News 3: Naturalization and Normalization (9 January 2020)}

The issue that attracts attention on the event of the DKI Jakarta flood in early 2020 is the concept of Normalization and Naturalization. These issues have been developed since 2019 and have become the most talked-about topic discussed in several media, print and electronic, and social media. One article discussing naturalization and normalization below is written by Sunjoto, the lecturer at Technical Faculty of Gajah Mada University, The Awardee of Kalpataru 1995, The Environment Adviser of Water Conservation. At the beginning of his writing, he explained both concepts of Naturalization and Normalization with each of its pluses and minuses.

The advantage of the naturalization method other than solving flood problems, it also soaks runoff or the flow of surface to become groundwater storage. However, the disadvantage of this method is that it will only be successful if all river flow areas (Daerah Aliran Sungai) are being fully managed. Meanwhile, in the case of the DKI Jakarta flood, part of its river flow area is in West Java Province. It contributes a significant debit of water into the Ciliwung river that goes through the area of DKI Jakarta.

The advantage of normalization is to solve the flood problem in an immediate manner. Managing it, including enlarging the river dimension, will drain the rain 
by polder and pumps. Netherland has tried this method, and the result is that the rainfall-runoff discharged were not turning into a puddle. The disadvantage of this method is that the flow will be disrupted when there is silting in the river and canal. Other than that, there is no conservation effort to add up the reserve of soil water.

\section{News 4: Failure in Handling Flood (31 January 2020)}

This article expressed the history of the Jakarta flood that has existed since the era of the Dutch colonial government.

Flood is not a new event in Jakarta. Since Jan Pieterzoon Coen built the city in the estuary of the Ciliwung river in 1619, floods have kept happening in Jakarta. Even though many efforts have been implemented, the Jakarta flood still happened. Only three years since being built in 1621, Batavia experienced a flood. Flood also happened in 1654 that caused the old city of Jakarta to be left behind by people. Slowly, the city's growth was headed to the South area of Jakarta.

The other paragraph described the historical record about the high number of raindrops in several times flood in Jakarta. The stress of flood disaster is described by identifying the causes of flood. This happened because of the intervention of people's habits in Jakarta.

However, the weather can not justify the Jakarta flood that claims at least 30 casualties. The cause of floods in Jakarta is climate, ecology, and social crises, such as the flow of runoff water from the upstream area. This happened because of the damage to the vegetation cap. The lessen of water reservoir lake and the shallowing of the river are because of sedimentation and trashes. The decline of the mainland is because of the absorption of soil water.

\section{News 5: Tangerang Face Difficulties in Handling Flood (February, $5^{\text {th }}$ 2020)}

This article is one of the articles that describes a flood that happened in the onemonth interval since the Jakarta flood in early 2020. In the beginning article, it was the flood in Tangerang being discussed. The majority of topics on the rest of the articles were about the Jakarta flood, namely, North Jakarta, South Jakarta, and Kemayoran.

Secretary of Water Resource Department DKI Jakarta Dudi Gardesi noted that the Muara Angke flood is not over because the stationer pump in Muara Angke reservoir is broken. The officer must only rely on the portable pump with a much lesser capacity to absorb the flood in Muara Angke. "I should double-check on this. Because all I heard is that the pump is broken because it is clogged by the trash", said Dudi Gardesi. Overall, 180 portable pumps are functioning to absorb the flood and puddles in Jakarta. This number has increased from the earlier 122 portable pumps. The pumps have capacity of around 75 liters - 1000 liters.

In Kemayoran, the management of Kemayoran complex North Jakarta has planned to prepare "sodetan" in the puddled tunnel since Saturday (25/1). This has become the short-term solution to overcome the puddled that happened twice there.

From the analysis of the five news with the elements of syntaxis, script, thematic, and rhetoric. On syntaxis, the researcher analyzes based on the form of phrases and sentences on each news. Kompas uses the inverted pyramid scheme that starts from the 
title, leads, episode, background, and closing. Kompas seems to construct the news from the point of view of experts and other experienced parties in DKI Jakarta flood handling from the previous periods. The pattern of syntaxis on the news of the DKI Jakarta flood in early 2020 emphasizes news on the cause of the flood, flood history in Jakarta to various solutions from physical construction are described in detail. This problem should be viewed not only as a problem of DKI Jakarta because it impacted the surrounding area. DKI Jakarta area intersects with other places, both cities and provinces. The thirteen river networks in DKI Jakarta are parts of river networks in West Java province and Banten. The central government and business activities being paralyzed for the past few days since it is fueled by thousands of people living around the Jabodetabek area. In some news, the lead framed the complexity of related areas so that it describes flood disaster context so widely until it moves further to the lawsuit of the number of people to DKI Governor.

On the background of information, all news indicate that the DKI Jakarta flood problem is so complicated that it should be communicated with concrete explanation equipped with many supporting data. Because flood disaster is a long experience in DKI, the public should get information in the form of numbers and direct results of the interview from the competent resources from their respective field. The coverage also highlighted the polemic between naturalization and normalization that later became the themes on other news that discuss flood handling solutions from the infrastructure part.

The news script does not only present an explanation of the cause of the flood and the loss as usually applied on other coverage of the disaster. The coverage on the script element is the component that has accuracy in the news element consisting of who, what, why, where, when, and how. The completeness of these elements on every content of the news gives a description of how the news focuses on all the things behind the DKI Jakarta flood event. Therefore print media has played its role as the messenger of meaningful information to people.

The element of who on the news exposed the parties related to the flood event. The quotation from resources comes from various competent parties such as experts, not only victims, as normally applied in other disaster news. The experts quoted by Kompas are namely academics, local and central government, local organizations, and observers. The variety of resources presented shows the dynamic of disaster events that are considered essential and need to be viewed from various points of view.

With the diverse resources on almost every news, the verification principle has been impelemnted well. The readers can obtain proportional information because there is confirmation effort to information that impacts the public. The direct quotation published on the news shows information validity test has been conducted responsibly. This process indicates Kompas' commitment as media who regularly conduct contacts with many related organizations and manage the database adequately.

The element of what on every news explains the various issues faced on the DKI Jakarta flood event. The element of what as the main information messenger gives information on the cause of flood disaster from many aspects. The news published is not only reporting facts but also trying to give full perception about the reality of DKI flood disaster during the relatively predictable time.

What element on the news can be seen from an article titled Disaster Control Evaluated. From this article, it can be viewed that hydrometeorology disaster like flood is actually predictable because it comes together with the rainy season. Every party, 
government, and society has anticipated the possibility of floods and landslides. This situation is in line with a study about hydrometeorology about the importance of surveillance of weather and climate characteristics, extreme weather, and climate forecasting. Excellent monitoring is an important input to develop a system in disaster countermeasure and build a culture (Sarvina, 2018). The use of monitoring is applied as a basis of the follow-up effort in avoiding disaster. As mentioned in the article, DKI Will Conduct Land Acquisition, the issue of flood disaster handling is very complex because there is a delayed work before the construction workings are completed by other related ministries.

The element of where on the news indicates the description of flood events on the macro level that impacted. The article with the title Tangerang Face Difficulties in Handling the Flood shows that DKI Jakarta's position near other cities significantly impacts flood disasters. This will make more sense if it is correlated with another article called Failure in Dealing with Flood, which describes Ciliwung river morphology. The river stretches across Jakarta and the surrounding area along with a flood map and thirteen rivers in DKI Jakarta, whose flows are connected with other areas in West Java province.

These news articles mean that business and government activities in DKI Jakarta are supported by people from a number of surrounding cities like Tangerang, Bekasi, Bogor, and Depok. Thus, once flood strikes, it will automatically paralyze the people of DKI Jakarta and people from neighboring cities. This is mainly because floods bring impacts on the running of public transportation.

The element of why on DKI Jakarta flood coverage that appears on every article consists of facts and an explanation of everything behind the flood event. For example, the articles called Naturalization and Normalization and Failure in Handling Flood detailed explanations of how river naturalization is DKI Jakarta's top priority and why it has not been completed yet. There was also a budget cut in the portion of flood handling. These explanations give readers that human intervention has a bigger contribution to flood disasters than natural phenomena.

The explanation of the cause of DKI Jakarta flood was being reported more clearly in the article called Failure in Handling Flood. This describes clearly that flood and water puddle has been a problem in Jakarta since the $17^{\text {th }}$ century. However, recently the big flood came more often since the number of the environment damaged has increased and land transfer function of water reserve into the residential and business area.

Furthermore, the DKI Jakarta flood disaster has attracted the public because of the need for information on the "how" solution to overcome the flood. The flood event in DKI Jakarta happened at high frequency, and the effort to find a solution has become the main discourse since the period of previous governors. Therefore, the flood solution has attracted public attention both in conventional mass media and social media.

From the "how" element on the articles with the title Naturalization and Normalization and DKI Jakarta Will Have Land Acquisition, the readers understand that Jakarta flood handling must be connected to layout and land use and must consider the upstream and downstream area. The plan of flood reduction in Jakarta that used the Bogor-Puncak-Cianjur area and other methods has not been followed until now. The news about naturalization and normalization that the DKI Governor has discussed as one of the solutions to handle floods appeared on a television channel. Some news coverage in Kompas about naturalization and normalization concepts 
presents explanations from experts about the "how" or process of both concepts, not only about "what".

The element of "how" focuses more on the solution of the flood and shows many explanations about "how" to handle the issue. They no longer dispute whether the DKI Jakarta flood in early 2020 was because of the heavy rain or a new natural event. The frequent DKI Jakarta flood events are different from other disaster events that require a "why" explanation. For example, on tsunami disaster in Pandeglang West Java province without any earthquake precedence at the end of 2018, earthquake, tsunami, and soil liquefaction happened simultaneously in Palu, Sigi, and Donggala mid-2018. The coverage of those disasters emphasizes the "what" aspect of the event or "why" that numerous disasters could happen naturally and why this kind of disaster could create so many victims.

The coverage of the "how" DKI Jakarta flood has become more apparent once the media explains DKI Jakarta flood handling infrastructure. What has been expressed by related organizations and offices leaders could clearly describe both steps that have or have not been taken yet in flood handling.

Therefore, generally, on the DKI Jakarta flood in early 2020, Kompas has comprehensively framed the news in such complete order by including the elements of what, who, why, where, and how. The frame of news related to disaster event starts from the historical aspect (what), who are responsible for handling the flood (who), many reasons why flood happened both in DKi and West Java area (why and where), and then what are the solutions needs to be done (how). Those elements indicate that the framing of the flood event in DKI Jakarta required an answer to be handled.

On a thematic structure, it was seen clearly how the coverage emphasized the facts are being written. Through the detailed information on the development infrastructure process of flood handling, Kompas articles choose the main theme in which sentences and explanations show the essential things that the public should understand behind the flood event in the nations' capital.

The description is written in a detailed manner by Kompas, for example, on the article called Failure in Flood Handling that describes the aspect of the flood cause or on the article that explains concepts of normalization and naturalization and their implementation on flood control management. The information, data, and explanation are expected to inspire readers, especially on looking at flood disasters from various aspects.

On every side of news, there is a solid connection between words or coherence. The sentence and explanation show about the subject from positive things, such as the solutions on their agenda. There are two main reasons why this subject becomes the spotlight for the public: First, flood disaster originally was a predictable phenomenon. Second, flood control management by DKI Jakarta, for example, infrastructure development like river normalization, has not been implemented. This indicates news control on the written articles over the important role played by the government, both central like Ministry of PUPR or DKI Jakarta government.

On the rhetorical structure, there is an option of style or words emphasized on dominant themes. Part of the news articles is supported by the black and white photos with relatively big size for about a quarter of paper size. The photo displayed in the article is to convince, support, and emphasize the meaning of facts being described in news narration. Another rhetoric element is the DKI Jakarta infographic map that shows 
an area that has experienced a flood, according to history. This kind of information has amplified the event covered in the news. Infographic form on display about data of Jakarta flood could convince the readers about the important things that happened in the past because most of the time, problems in the past are not considered essential history notes as they do not appear on the surface. Information about DKI Jakarta history is required to guide today's improvement.

All rhetorical elements on the news point out that on DKI Jakarta flood disaster event, they no longer discuss the victims' misery but focus more on the program of flood handling, especially on infrastructure. Some of the pictures on the news reveal the DKI Jakarta flood risk distributions map. The picture demonstrates the normalization process of Ciliwung river that has not been completed and the residential of low-class society covered by the puddle.

Rhetorical elements of photos and infographics indicate that the news content highlighted the rational argumentation of the flood handling program by the Ministry of PUPR and DKI Jakarta government, especially on the most captivating issues like normalization and naturalization. Since there is an emphasis on that part, the description of infrastructure issues is also completed with pictures. These pictures can clarify the description and build a better understanding of how basic the infrastructure problems that are urgent to be solved for flood handling program.

Therefore, it can be said that Kompas has fulfilled one of the public's daily needs toward media, which is surveillance. Even without realizing it, people always use media every day to find out about many things in life. From the media, people get the most updated information, references for daily activities, and follow-up information on important events they wish to know about (Turow, 2014). In relation to the case of the DKI Jakarta flood, Kompas tried to meet the public's need in surveillance function by presenting in-depth news and framing the news scientifically. The news published informs some facts like other media that present the relatively same information and uses the approach on various physical construction. This different approach could give another perspective for readers on concrete mitigation solutions to flood disasters.

In disaster situations in which the public requires trustworthy information, media is demanded to provide enlightenment in telling the facts and giving critics to the government. In this case, the surveillance function by media has been conducted. On the other side, Kompas has done the interpretation function comprehensively by presenting facts and providing analysis on every theme being covered. Therefore, other media functions such as coverage linkage between one event with another previous event (history of flood) and its impact (not only in DKI Jakarta but also in surrounding cities like Tangerang and Bekasi) have been fulfilled. Media function as the transmission of value is also seen on the description of various perspectives that emphasize that initially, frequent hydrology events during the rainy season could be anticipated, mitigated, and managed optimally to prevent it from turning into a disaster. These have been shown on some news that highlighted that DKI Jakarta must be connected with spatial and land use and its upstream area. Media has served more than just information function and education as it has presented a number of facts with scientific framings.

Meanwhile, the value transmission process also presents on the news that provides flood history and a rational explanation to maintain history memory with the concept of social betterment. Therefore, this is in line with the concept that emphasizes that the transmission function of mass media has an important role as a cultural keeper and transmitter. Various documentation of event, news, and story could be documented by 
media. This can be called a historical transmission. Whereas, from the contemporary transmission, mass media can transmit values among communities and contemporary people that sometimes bring societal changes, as noted by the anthropologist (Vivian, 2008).

\section{Conclusion}

Generally, in framing the DKI Jakarta flood case in early 2020, Kompas media focused on the government's role in creating a rational solution in controlling floods that have been seen on almost all of its coverage. The flood disaster initially was stated by DKI Governor as a purely natural event, but in Kompas' coverage, it highlighted more on the lack of human intervention. The news framing describes various technical and operational problems in managing floods that directly lead readers to question and demand a better answer from the DKI Jakarta government.

Kompas is considered comprehensive in framing flood events from the causal aspect. The framing includes the Ciliwung river management with the debate on naturalization and normalization concept, land acquisition process required for river normalization, the budget-cutting issue in flood handling, the broken water pumps, dysfunctional disaster early warning system, and the issue of no coordination between local and central government.

News on print media indirectly can be utilized to clarify distorted news on social media. For example, those associated with DKI flood with political issues. News coverage on the DKI flood also serves as the media control function towards authority because only professional media has the guts to deliver critics for the government's role. The critics from the media also required to encourage the government to be more active, agile, and serious in handling flood problems in the nation's capital.

However, the article's content criticizing the government still appears to be mindful and cautious. Kompas does not focus on emphasizing the facts, analysis, and opinion that create confrontation between local and central government or two political poles that are still in confrontation since the last election. Kompas'assertiveness has managed to avoid news coverage that leads to a speculative or dramatical narrative that could bring anxiety to people

As mainstream media, Kompas has also not been trapped on merely capturing flood disasters in black and white nature as other disaster news coverage. Therefore, there is contribution as optimum reflective value for readers. On other media's coverage about the disaster, media usually play as an irresponsible provocator that worsens the conflict. News coverage on topics like the number of casualties, negligence in providing aid, and failure to rescue people because of dysfunctioning early warning system would easily lead public opinion about the problems and impact of a disaster than on the solution.

With its position as reputable print media, Kompas has greater potential during the disaster. The researcher's criticism of this media in framing the news in the DKI flood in early 220 is as follows. First, in implementing its surveillance function, print media as watchdogs not only help parties distribute aids but also have to report the use of aid to prevent the misuse of aid for personal or group interest. Secondly, on the article resources, Kompas should invite more local entrepreneurs to give descriptions from a microeconomic perspective significantly affected when DKI Jakarta's business was paralyzed during the flood. The public readers should obtain information directly 
about the impact of the flood that causes loss on individual and business scale levels. Thirdly, on media education function, Kompas has not provided news on how people in DKI Jakarta could use rainwater for daily needs that many other countries in the world have practiced. With the abovementioned suggestions, the researcher believes that mass media could serve as the society empowerment agent on every natural disaster in Indonesia.

\section{References}

Adi, S. (2013). Karakterisasi Bencana Banjir Bandang di Indonesia. Jurnal Sains Dan Teknologi Indonesia, 15(1), 42-51. https://doi.org/https://doi.org/10.29122/jsti.v15i1.938

Ali, Z. S. (2013). Media Myths and Realities in Natural Disasters. European Journal of Business and Social Sciences, 2(1), 125-133. http://ww31.ejbss.com/recent.aspx

Annapisa, M. (2018). Peran Media Cetak Lokal dalam Komunikasi Bencana sebagai Pendukung Manajemen Bencana. Buletin Pembangunan Berkelanjutan, 2(1), 102-115. https://journal.uir.ac.id/index.php/buletinpembangunan/article/view/3856

Arif, A. (2014). Jurnalisme Bencana: Tugas Suci, Praktik Cemar. https://www.remotivi.or.id/amatan/32/jurnalisme-bencana-tugas-suci-praktikcemar\#

Asteria, D. (2016). Optimalisasi Komunikasi Bencana di Media Massa sebagai Pendukung Manajemen Bencana. Jurnal Komunikasi Ikatan Sarjana Komunikasi Indonesia, 1(1), 1-11. https://doi.org/https://doi.org/10.25008/jkiski.v1i1.30

Eriyanto. (2002). ANALISIS FRAMING Konstruksi, Ideologi, dan Politik Media (1st ed.). LKiS.

Greenberg, J., \& Scanlon, T. J. (2016). Old Media, New Media, and the Complex Story of Disasters. Oxford Research Encyclopedia of Natural Hazard Science. https://doi.org/10.1093/ACREFORE/9780199389407.013.21

Handayani, V. W., Soelistiono, S., \& Sylvaranto, T. (2018). Pengaruh Modul Bencana Gunung Api terhadap Peningkatan Kesiapsiagaan Menghadapi Bencana Gunung Api Melalui Facebook Studi Kasus: Guru SD Pengguna FB di Kecamatan Sumber Wringin Kabupaten Bondowoso. JIABI: Jurnal Ilmiah Administrasi Bisnis Dan Inovasi, 2(2), 236-263. https://doi.org/https://doi.org/10.25139/jai.v2i2.1126

Haryanto, I. (2018). Performa Media, Jurnalisme Empati, dan Jurnalisme Bencana: Kinerja Televisi Indonesia dalam Peliputan Bencana (Kasus Liputan TV One terhadap Hilangnya Air Asia QZ 8501). Ultimacomm: Jurnal Ilmu Komunikasi, 8(1), 77-89. https://doi.org/10.31937/ultimacomm.v8i1.818

Istiqomah, I. (2019). Pengaruh Pemberitaan Bencana Alam di Harian Serambi Indonesia Terhadap Kesadaran Masyarakat. Jurnal Studi Komunikasi, 3(1), 57-69. https://doi.org/10.25139/jsk.v3i1.1423

Kompas. (2020). Kerugian Banjir Capai Rp 1 Triliun. Kompas, 13 Januari 2020. https://www.kompas.id/baca/utama/2020/01/13/kerugian-banjir-capai-rp-1-triliun/

Lestari, P., Ramadhaniyanto, B., \& Wardyaningrum, D. (2018). Pemberitaan di Media Online untuk Pengurangan Risiko Bencana Gunung Sinabung. Jurnal Kajian Komunikasi, 6(1), 106. https://doi.org/10.24198/jkk.v6i1.15168

Mardikaningsih, S. M., Muryani, C., \& Nugraha, S. (2017). Studi Kerentanan dan Arahan Mitigasi Bencana Banjir di Kecamatan Puring Kabupaten Kebumen Tahun 2016. Jurnal Geo Eco, 3(2), 157-163. 
https://jurnal.uns.ac.id/GeoEco/article/view/14312/11896

Nazaruddin, M. (2015). Jurnalisme Bencana di Indonesia, Setelah Sepululi Tahun. Jurnal Komunikasi, 10(1), 79-88. https://doi.org/https://doi.org/10.20885/komunikasi.vol10.iss1.art8

Noviani, R. (2012). Bencana dalam Narasi Media: Kajian Naratif Berita tentang Erupsi Merapi 2010 dalam Program Breaking News di MetroTV. In Sekolah Pascasarjana Universitas Gadjah Mada.

Peary, B. D. M., Shaw, R., \& Takeuchi, Y. (2012). Utilization of Social Media in the East Japan Earthquake and Tsunami and its Effectiveness. Journal of Natural Disaster Science, 34(1), 3-18. https://doi.org/https://doi.org/10.2328/jnds.34.3

Rahayu, P. B., Asrul, L., \& Akbar, M. (2014). Peran Media Cetak Lokal dalam Mitigasi Bencana Banjir terhadap Kesadaran Masyarakat di Kota Makassar. Jurnal Komunikasi KAREBA, 3(1), 68-76. https://doi.org/https://doi.org/10.31947/kjik.v3i1.572

Rosyida, A., Nurmasari, R., \& Suprapto. (2019). Analisis Perbandingan Dampak Kejadian Bencana Hidrometerologi dan Geodlogi di Indonesia dilihat dari Jumlah Korban dan Kerusakan (Studi: Data Kejadia Bencana Indonesia 2018). Jurnal Dialog Penanggulangan Bencana, 10(No. 1), 12-21. https://perpustakaan.bnpb.go.id/jurnal/index.php/JDPB/article/view/127

Sarvina, Y. (2018). Aspek Hidrometeorologi Dalam Menumbuhkan Budaya Sadar Bencana di Indonesia. Jurnal Dialog Penanggulangan Bencana, 9(1), 9-17. https://bnpb.go.id/uploads/24/jurnal-vol-9-no-1-2018.pdf

Setiawan, H., Jalil, M., S, M. E., Purwadi, F., S, C. A., Brata, A. W., \& Jufda, S. (2020). Analisis Penyebab Banjir di Kota Samarinda. Jurnal Geografi Gea, 20(1), 39-43. https://doi.org/https://doi.org/10.17509/gea.v20i1.22021

Subiyanto, I. (2016). Melacak Mitos Merapi :Peka Membaca Bencana, Kritis Terhadap Kearifan Lokal (Cet. 1). Jogja Bangkit Publisher.

Sugiyono. (2010). Memahami penelitian kualitatif. Alfabeta.

Sukmono, F. G., \& Junaedi, F. (2018). Menggagas Jurnalisme Optimis dalam Pemberitaan tentang Bencana. Jurnal ILMU KOMUNIKASI, 15(1), 107-119. https://ojs.uajy.ac.id/index.php/jik/article/view/882/1156

Turow, J. (2014). Media Today: Mass Communication in a Converging World. In Media Today. Routledge. https://doi.org/10.4324/9780203111581

Vivian, J. (2008). Teori Komunikasi Massa. Kencana Prenada Media.Zaheer, L. (2016). Natural Catastrophes and Role of Pakistani Mass Media. Journal of Political Studies, 23(1), 207-232. http://pu.edu.pk/home/journal/6/V23_Issue_1_2016.html 